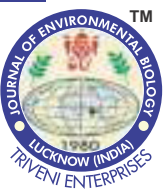

\title{
Effect of organic and conventional farming practices on soil microbial population
}

\begin{tabular}{lll}
\hline Paper received: 05.04.2018 Revised received: 12.06 .2018 & Re-revised received: 16.06 .2018 \\
\hline
\end{tabular}

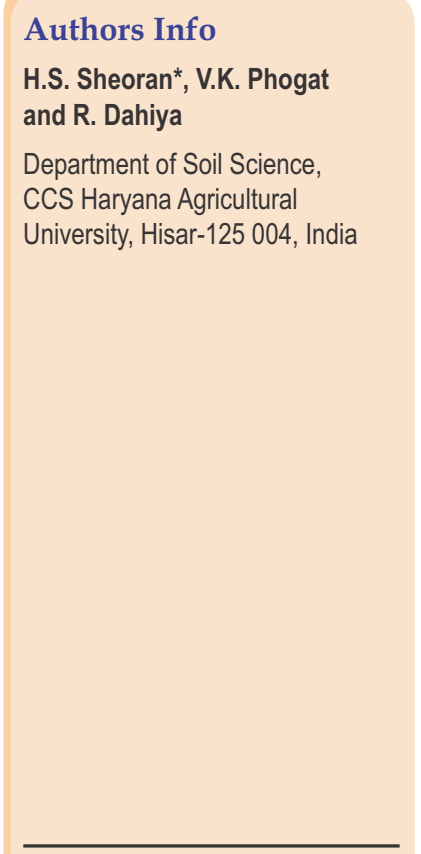

*Corresponding Author Email : sheoranhardeep2008@gmail.com

\section{Edited by \\ Dr. Asit Mandal}

\section{Reviewed by}

Dr. Sunanda Biswas

Dr. Kuppu Rajendran

\section{Abstract}

Aim : Microbial community has an integral role in farming, but there is limited understanding of the complex response of microbial populations to organic and conventional farming systems. Therefore, the present study was carried out to study the effect of organic and conventional farming practices on soil microbial population in Haryana.

Methodology : Fifty surface soil samples (0-15 $\mathrm{cm})$ were collected from organic and their adjoining conventional farms at 11 districts of Haryana. Soil samples were processed and analyzed for Rhizobium, Azotobacter, Azospirillium and phosphorous solubilizing bacterial (PSB) counts for the two types of farming systems.

Results : In comparison to conventional farming system, overall, population of PSB (which was $25.71 \times 10^{4} \mathrm{CFU} \mathrm{g}^{-1}$ soil) increased significantly to $36.91 \times 10^{4}$ CFU $\mathrm{g}^{-1}$ soil (an increase of $43.5 \%$ ). Similarily, Rhizobium population in organic farming system increased from $29.26 \times 10^{4} \mathrm{CFU} \mathrm{g}^{-1}$ soil to $42.14 \times 10^{4} \mathrm{CFU} \mathrm{g} \mathrm{g}^{-1}$ soil (an increase of 44.1\%). The population of Azotobacter increased significantly from $15.83 \times 10^{4}$ to $22.01 \times 10^{4} \mathrm{CFU} \mathrm{g}^{-1}$ soil $(39.0 \%)$, while Azospirillium population increased from $13.66 \times 10^{4}$ to $20.10 \times 10^{4} \mathrm{CFU} \mathrm{g}^{-1}$ with an increase of $47.1 \%$. Thus, it is clear from the results that organic nutrient sources showed a stimulating influence on the microbial populations of organic farming.

Interpretation : Higher microbial population recorded in organic farming in comparison to conventional farming leads to better soil health and increased productivity.

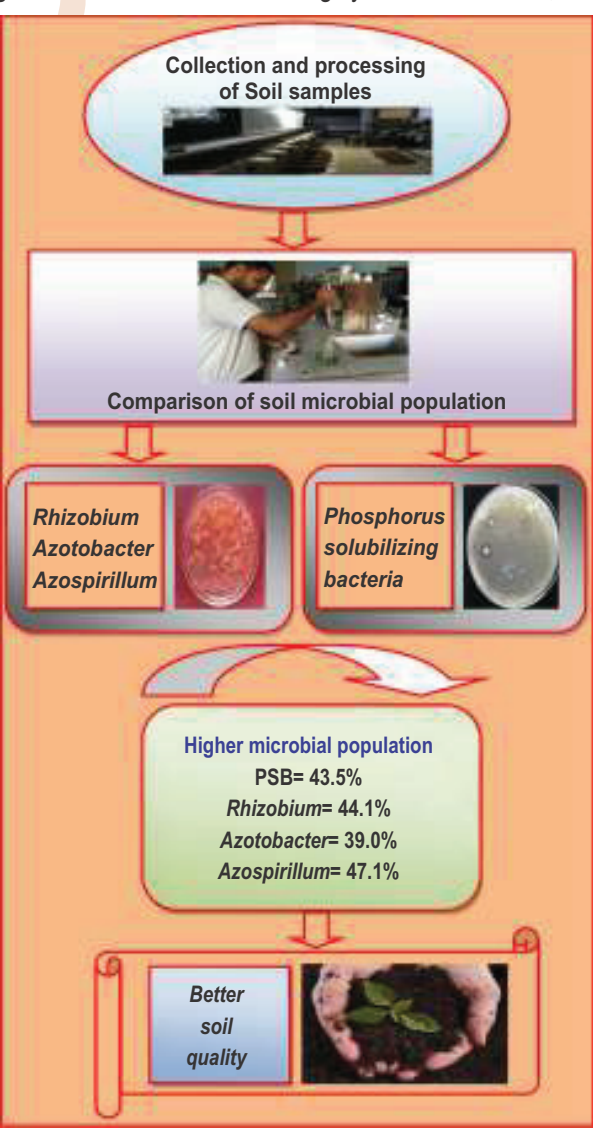

Key words: Azospirillium, Azotobacter, Conventional farming system, Organic nutrients, Rhizobium

How to cite: Sheoran H.S., V.K. Phogat and R. Dahiya : Effect of organic and conventional farming practices on soil microbial population. J. Environ. Biol., 40, $125-129(2019)$. 


\section{Introduction}

Growing concerns about the environmental, economic and social effects of chemical-dependent conventional farming system have led farming community, scientists, and researchers to seek alternative systems that make agriculture more sustainable while providing safe and quality food for ever growing population. Among alternative farming systems, organic farming is more popular now-a-days, however, both organic and conventional farming employ their own methods and practices, and have their own challenges and implications, particularly with respect to the impending global food crisis coupled with climate change (Uddin et al., 2016). It has, already been witnessed that traditional methods of food production are failing to provide a solution to the expected food shortage (lqbal, 2010). At the same time, current degradation rates of the natural resources have serious implications for their management and need for increased food production (Warner et al., 2010). These issues are compelling to think about some improved farming systems/practices, which may feed the increasing population while maintaining the ecosystems. Organic farming is a holistic approach to food production which is sustainable in terms of its long term effects on ecosystem by excluding or limiting the use of fertilizers, pesticides and genetically modified organisms (Pimentel et al., 2005).

In recent years, multiple studies comparing conventional and organic agriculture have reported differences in soil properties, higher microbial activity and diversity in organically managed soils, or distinct microbial profiles between the two systems (Wu et al., 2008). Effect of different farm management practices (conventional and organic) on the soil biochemical and microbial populations have been studied and researchers have reported that microbial population (bacteria, fungi, actinomycetes, Beijerinckia, Azotobacter, Rhizobium, Bacillus and phosphobacteria) were higher in soils from organic farming than sustainable and conventional farms (Carine et al., 2009; Sudhakaran et al., 2013; Uddin et al., 2016) Bobulska et al. (2015) reported large differences between the organic and conventional sites in terms of microbiological properties, which are sensitive soil indicators of changes occurred under different farming systems.

The study confirmed the positive influence and higher microbial activity indices of eco-friendly farming practices $(36 \%$ higher enzymatic activity, $65 \%$ higher soil respiration content, $60 \%$ higher soil microbial biomass carbon content) compared to conventional farming system. Moeskops et al. (2010) compared the effect of organic and conventional farming practices on soil microbial dynamics in West Java, Indonesia and concluded that based on the amounts of marker fatty acids, all microbial groups considered (actinomycetes, total bacteria and fungi) were significantly higher in organically managed soil than in soil from conventional farms. Though various studies with regard to biological properties of soils have been investigated and compared, the conventional with organic farming practices, but noticeable changes in soil properties, can occur only after longterm organic farming. The real picture of overall sustainability in organic farming, however, continues to face many challenges. For instance, there is disagreement over the organic farming in fulfilling the requirement of food production and difficult to evaluate its sustainability. Such concerns require greater understanding of the long-term effects of organic farming system and its feasibility as an alternative to the conventional practices, for sustainable use of natural resources. Keeping in view the above concerns, the present study was planned with the objective to determine the effect of organic and conventional farming practices on soil microbial population in Haryana.

\section{Materials and Methods}

Study area : Organic farms under different cropping systems, vegetables and horticultural crops and their adjoining conventional farms were identified at eleven districts of Haryana, namely Sirsa, Fatehabad, Hisar, Jind, Kaithal, Karnal, Kurukshetra, Ambala, Panchkula, Yamunanagar and Panipat and their soil properties were studied. A total of 50 soil samples at $0-15 \mathrm{~cm}$ depth, in triplicates, were collected from two types of farming systems and analysed for viable counts of Rhizobium, Azotobacter, Azospirillium and phosphorous solubilizing bacteria (PSB) in soils under organic and conventional farming practices.

Processing of soil samples and methods of analysis : Soil samples collected were refrigerated at $4^{\circ} \mathrm{C}$ for analysis of the microbiological properties. The serial dilution plating method (Lindow et al., 1978) was used for enumeration of viable counts for Rhizobium, Azotobacter, Azospirillium and PSB. Plates with serial dilution plating were incubated for 5 days and the number of colonies on different dilution media plates were recorded and population per gram soil was enumerated.

Statistical analysis : The significance of treatment effects was analyzed using two factorial RBD analysis using OP Stat, CCS HAU Hisar, software.

\section{Results and Discussion}

Viable counts of phosphorous solubilizing bacteria, Rhizobium, Azotobacter and Azospirillium: The organic farming practices significantly influenced the microbial populations in soil and the phosphorous solubilizing bacteria (PSB), Rhizobium, Azotobacter and Azospirillium populations were higher in the organic farming as compared to conventional farm system (Table 1, 2). Under conventional farming system, the PSB showed variations from $8.0 \times 10^{4}$ to $52.4 \times 10^{4}$, Rhizobium population varied from $10.8 \times 10^{4}$ to $57.3 \times 10^{4} \mathrm{CFU} \mathrm{g}^{-1}$ soil at different locations (Table 1). The corresponding range of population of PSB and Rhizobium under organic farming ranged from $13.1 \times 10^{4}$ to $67.8 \times 10^{4} \mathrm{CFU} \mathrm{g}^{-1}$ and $16.3 \times 10^{4}$ to $86.3 \times 10^{4} \mathrm{CFU}$ $\mathrm{g}^{-1}$ soil, respectively. Similarly, under conventional farming system, Azotobacter population ranged from $6.7 \times 10^{4}$ to $32.3 \times 10^{4}$ 
Table 1: Effect of organic and conventional farming practices on Phosphorus solubilizing bacteria and Rhizobium populations in soil at different locations

\begin{tabular}{|c|c|c|c|c|c|c|c|c|}
\hline \multicolumn{2}{|c|}{$\begin{array}{l}\text { Location District } \\
\text { (L) }\end{array}$} & \multirow[t]{2}{*}{ Village } & \multicolumn{3}{|c|}{$\begin{array}{l}\text { Phosphorus solubilizing bacteria } \\
\left.\text { (CFU g }{ }^{-1} \text { soil } \times 10^{4}\right)\end{array}$} & \multicolumn{3}{|c|}{$\begin{array}{c}\text { Rhizobium } \\
\left(\text { CFU g }{ }^{-1} \text { soil } \times 10^{4}\right)\end{array}$} \\
\hline & & & Conventional & Organic & Mean & Conventional & Organic & Mean \\
\hline$L_{1}$ & Panchkula & Billa & 11.3 & 15.2 & 13.2 & 14.4 & 21.3 & 17.9 \\
\hline $\mathrm{L}_{2}$ & Sirsa & Mamad Khera & 8.0 & 13.1 & 10.6 & 10.8 & 16.3 & 13.5 \\
\hline $\mathrm{L}_{3}$ & Panipat & Kurad & 18.9 & 21.0 & 20.0 & 21.5 & 30.3 & 25.9 \\
\hline $\mathrm{L}_{4}$ & Panchkula & Tabar & 17.0 & 26.8 & 21.9 & 18.4 & 25.6 & 22.0 \\
\hline$L_{5}^{4}$ & Sirsa & Kharian & 19.8 & 29.4 & 24.6 & 24.6 & 29.6 & 27.1 \\
\hline $\mathrm{L}_{6}$ & Fatehabad & Zandli Kalan & 16.6 & 24.5 & 20.5 & 18.7 & 26.3 & 22.5 \\
\hline $\mathrm{L}_{7}$ & Fatehabad & Hasinga & 14.6 & 20.3 & 17.4 & 19.5 & 24.6 & 22.1 \\
\hline $\mathrm{L}_{8}$ & Hisar & Shahpur & 21.4 & 28.7 & 25.1 & 22.8 & 29.5 & 26.1 \\
\hline $\mathrm{L}_{9}$ & Hisar & Biyana Khera & 24.0 & 34.5 & 29.2 & 25.8 & 32.5 & 29.1 \\
\hline$L_{10}$ & Panipat & Bahuapur & 17.2 & 25.3 & 21.3 & 29.3 & 36.5 & 32.9 \\
\hline $\mathrm{L}_{11}$ & Jind & Ikkas & 19.7 & 28.4 & 24.0 & 24.3 & 38.8 & 31.5 \\
\hline $\mathrm{L}_{12}$ & Yamunanagar & Amadalpur & 22.5 & 32.0 & 27.3 & 20.5 & 34.5 & 27.5 \\
\hline $\mathrm{L}_{13}$ & Jind & Balerkha & 20.8 & 33.1 & 26.9 & 29.3 & 47.8 & 38.5 \\
\hline $\mathrm{L}_{14}$ & Kaithal & Kailram & 26.3 & 36.8 & 31.5 & 32.5 & 40.1 & 36.3 \\
\hline $\mathrm{L}_{15}$ & Kurukshetra & Mangoli Jattan & 28.0 & 38.8 & 33.4 & 34.3 & 41.8 & 38.0 \\
\hline $\mathrm{L}_{16}$ & Kaithal & Hajwana & 25.8 & 42.1 & 33.9 & 31.8 & 46.3 & 39.0 \\
\hline $\mathrm{L}_{17}$ & Hisar & Ramayan Daderi & 20.7 & 39.3 & 30.0 & 28.6 & 44.2 & 36.4 \\
\hline $\mathrm{L}_{18}$ & Panipat & Sink & 33.1 & 45.8 & 39.5 & 34.6 & 44.6 & 39.6 \\
\hline $\mathrm{L}_{19}$ & Yamunanagar & Kandroli & 39.6 & 49.5 & 44.6 & 37.8 & 52.5 & 45.1 \\
\hline $\mathrm{L}_{20}$ & Fatehabad & Gilla Khera & 28.8 & 41.3 & 35.1 & 35.7 & 49.3 & 42.5 \\
\hline $\mathrm{L}_{21}$ & Sirsa & Shahpur Begu & 32.4 & 51.2 & 41.8 & 42.3 & 53.8 & 48.0 \\
\hline $\mathrm{L}_{22}$ & Kaithal & Sikanderpur kheri & 37.6 & 55.4 & 46.5 & 23.8 & 57.8 & 40.8 \\
\hline $\mathrm{L}_{23}$ & Jind & Palwan & 49.2 & 64.2 & 56.7 & 57.3 & 86.3 & 71.8 \\
\hline $\mathrm{L}_{24}$ & Karnal & Kachhwa & 37.2 & 58.2 & 47.7 & 47.2 & 69.6 & 58.4 \\
\hline $\mathrm{L}_{25}$ & Ambala & Sherpur Sulkhani & 52.4 & 67.8 & 60.1 & 46.3 & 73.8 & 60.0 \\
\hline \multicolumn{3}{|l|}{$\overline{\text { Mean }}$} & 25.7 & \multicolumn{2}{|l|}{36.9} & 29.3 & \multicolumn{2}{|l|}{42.1} \\
\hline at $5 \%$ & & & $\begin{array}{l}\text { Location }(L)= \\
\text { Farming syste }\end{array}$ & $\Rightarrow=0$. & & $\begin{array}{l}\text { Location }(L)= \\
\text { Farming sys }\end{array}$ & $=1.2$, & \\
\hline
\end{tabular}

CFU g ${ }^{-1}$ soil, while those of Azospirillium varied between $3.6 \times 10^{4}$ to $35.1 \times 10^{4} \mathrm{CFU} \mathrm{g}^{-1}$ soil at different locations (Table 2). The corresponding range of Azotobactor and Azospirillium population under organic farming was $10.0 \times 10^{4}$ to $36.7 \times 10^{4} \mathrm{CFU} \mathrm{g}^{-1}$ soil and $5.3 \times 10^{4}$ to $40.0 \times 10^{4} \mathrm{CFU} \mathrm{g}^{-1}$ soil, respectively. Overall, organic farming resulted in a significant increase in population of PSB from $25.7 \times 10^{4}$ to $36.9 \times 104$; Rhizobium from $29.3 \times 10^{4}$ to $42.1 \times 10^{4}$, Azotobactor from $15.8 \times 10^{4}$ to $22.0 \times 10^{4}$ and Azospirillium from $13.7 \times 10^{4}$ to $20.1 \times 10^{4} \mathrm{CFU} \mathrm{g}^{-1}$ soil. The percent increase in population of PSB, Rhizobium, Azotobacter and Azospirillium was observed to be $43.5,44.1,39.0$ and $47.1 \%$, respectively, upon shifting from conventional to organic farming system.

It was observed that the increase in population of PSB under organic farming was significant in all the different textured soils, while in case of Rhizobium, Azotobacterand Azospirillium, it was non-significant in sandy soils as compared to conventional system. As far as cropping system is concerned, it is difficult to compare the microbial population of two types of farming systems as the soils of the study area are under organic farming practices for 2 to 17 years. Organic nutrient sources showed a stimulating influence on the microbial population such as phosphatesolubilizing bacteria (PSB) and other nitrogen fixing microbes like Rhizobium, Azotobacter and Azospirillium, as seen by the increase in their viable counts in soil.

These soil microbial population were significantly greater with organics as compared to conventional system of farming. Microbial population (PSB, Rhizobium, Azotobacter and Azospirillium) was found to be higher upon shifting from conventional to organic farming system (Schjonning et al., 2002; Crecchioa et al., 2004; Melero, 2006; Araujo, 2009; Amaral et al., 2011) due to the permanent input of organic residues with high $\mathrm{C} / \mathrm{N}$ ratio. Further, it may be attributed to the fact that in the organic system large carbon inputs in the form of organic 
Table 2 : Effect of organic and conventional farming practices on Azotobacter and Azospirillium populations in soil at different locations

\begin{tabular}{|c|c|c|c|c|c|c|c|c|}
\hline \multirow{2}{*}{$\begin{array}{l}\text { Location } \\
\text { (L) }\end{array}$} & \multirow{2}{*}{$\begin{array}{l}\text { District } \\
\text { Conventional }\end{array}$} & \multirow{2}{*}{$\begin{array}{l}\text { Village } \\
\text { Organic }\end{array}$} & \multicolumn{3}{|c|}{ Azotobacter (CFU g ${ }^{-1}$ soil $\times 10^{4}$ ) } & \multicolumn{3}{|c|}{ Azospirillium (CFU g ${ }^{-1}$ soil $\times 10^{4}$ ) } \\
\hline & & & Mean & Conventional & Organic & Mean & & \\
\hline $\mathrm{L}_{1}$ & Panchkula & Billa & 11.1 & 13.1 & 12.1 & 5.7 & 6.9 & 6.3 \\
\hline $\mathrm{L}_{2}$ & Sirsa & Mamad Khera & 6.7 & 10.0 & 8.4 & 3.6 & 5.3 & 4.4 \\
\hline $\mathrm{L}_{3}$ & Panipat & Kurad & 9.0 & 12.3 & 10.7 & 6.3 & 10.2 & 8.3 \\
\hline $\mathrm{L}_{4}$ & Panchkula & Tabar & 13.1 & 16.3 & 14.7 & 9.2 & 15.9 & 12.6 \\
\hline $\mathrm{L}_{5}$ & Sirsa & Kharian & 9.2 & 13.6 & 11.4 & 10.8 & 12.6 & 11.7 \\
\hline $\mathrm{L}_{6}$ & Fatehabad & Zandli Kalan & 13.3 & 16.2 & 14.7 & 6.6 & 8.6 & 7.6 \\
\hline $\mathrm{L}_{7}$ & Fatehabad & Hasinga & 11.1 & 18.2 & 14.7 & 5.9 & 7.2 & 6.6 \\
\hline $\mathrm{L}_{8}$ & Hisar & Shahpur & 9.8 & 14.0 & 11.9 & 8.2 & 14.8 & 11.5 \\
\hline $\mathrm{L}_{9}$ & Hisar & Biyana Khera & 14.2 & 21.2 & 17.7 & 9.4 & 17.4 & 13.4 \\
\hline $\mathrm{L}_{10}$ & Panipat & Bahuapur & 12.6 & 19.9 & 16.2 & 7.1 & 15.6 & 11.3 \\
\hline$L_{11}$ & Jind & Ikkas & 9.8 & 17.6 & 13.7 & 9.5 & 16.1 & 12.8 \\
\hline $\mathrm{L}_{12}$ & Yamunanagar & Amadalpur & 15.4 & 19.3 & 17.3 & 11.5 & 18.9 & 15.2 \\
\hline $\mathrm{L}_{13}$ & Jind & Balerkha & 13.8 & 22.4 & 18.1 & 13.1 & 21.6 & 17.4 \\
\hline $\mathrm{L}_{14}$ & Kaithal & Kailram & 14.9 & 24.5 & 19.7 & 12.1 & 19.5 & 15.8 \\
\hline $\mathrm{L}_{15}$ & Kurukshetra & Mangoli Jattan & 19.2 & 23.1 & 21.1 & 13.1 & 22.8 & 18.0 \\
\hline $\mathrm{L}_{16}$ & Kaithal & Hajwana & 16.3 & 21.4 & 18.9 & 15.5 & 21.2 & 18.4 \\
\hline$L_{17}$ & Hisar & Ramayan Daderi & 19.2 & 25.0 & 22.1 & 14.7 & 18.8 & 16.7 \\
\hline $\mathrm{L}_{18}$ & Panipat & Sink & 16.7 & 26.8 & 21.7 & 21.4 & 28.0 & 24.7 \\
\hline $\mathrm{L}_{19}$ & Yamunanagar & Kandroli & 19.0 & 26.5 & 22.7 & 16.5 & 24.3 & 20.4 \\
\hline $\mathrm{L}_{20}$ & Fatehabad & Gilla Khera & 21.3 & 27.7 & 24.5 & 19.0 & 25.5 & 22.3 \\
\hline $\mathrm{L}_{21}$ & Sirsa & Shahpur Begu & 18.4 & 28.0 & 23.2 & 16.4 & 29.2 & 22.8 \\
\hline $\mathrm{L}_{22}$ & Kaithal & Sikanderpur kheri & 22.3 & 30.7 & 26.5 & 23.1 & 32.2 & 27.7 \\
\hline $\mathrm{L}_{23}$ & Jind & Palwan & 32.3 & 36.7 & 34.5 & 35.1 & 40.0 & 37.6 \\
\hline $\mathrm{L}_{24}$ & Karnal & Kachhwa & 24.0 & 34.2 & 29.1 & 25.6 & 34.3 & 30.0 \\
\hline $\mathrm{L}_{25}$ & Ambala & Sherpur Sulkhani & 22.8 & 31.7 & 27.2 & 21.8 & 35.6 & 28.7 \\
\hline \multicolumn{3}{|l|}{ Mean } & 15.8 & 22.0 & & 13.7 & 20.1 & \\
\hline \multicolumn{3}{|l|}{$\mathrm{CD}$ at $5 \%$} & \multicolumn{3}{|c|}{$\begin{array}{l}\text { Location }(L)=1.6 \\
\text { Farming system }(F)=0.5, L \times F=2.3\end{array}$} & \multicolumn{3}{|c|}{$\begin{array}{l}\text { Location }(\mathrm{L})=2.1 \text {, } \\
\text { Farming system }(F)=0.6, \mathrm{~L} \times \mathrm{F}=2.9\end{array}$} \\
\hline
\end{tabular}

amendment is applied that supply available carbon. Additionally, the increase in population of PSB, Rhizobium, Azotobacter and Azospirillium in organic farming practices is, probably, also due to the large substrate (carbon) available for microbial growth contained in the organic amendments (Jadhav et al., 2016). Therefore, overall, microbial population was higher in the organically managed soils due to high carbon input in the soil.

The better level of biological quality of soils under organic farming system was due to regular addition of organic materials in the surface layer (Dhaliwal et al., 2009). Increased availability of substrates ( $\mathrm{C}$ and $\mathrm{N}$ ) required for microbial population buildup could be the probable reason for this increase (Bunemann et al., 2006; Sudhakaran et al., 2013). Uddin et al. (2016) studied the impact of organic and conventional practices on the physicochemical properties, behavior and persistence of plant beneficial microorganisms, including Rhizobium, Azotobacter, phosphate solubilizing bacteria etc., and reported that population of beneficial soil microbes and health properties including $\mathrm{pH}$, nitrogen content, organic matter, phosphorus, K, Ca and S increased significantly in the compost-amended soils compared to the conventional practices. Similar trend was also followed in the case of viable counts of Rhizobium, Azotobacter, Azospirillium and PSB. Higher microbial population in clay loam soils may be due to higher organic matter content, water retention characteristics and nutrient availability (Grayston et al., 2004) along with the higher carbon content in these soils.

From the research findings, it can be concluded that adopting of organic farming showed a stimulating influence on the $\mathrm{N}$-fixing microbial populations of Rhizobium, Azotobacter and Azospirillium along with phosphate solubilizing bacteria. Overall, soil microbial populations were higher in soils under organic farming, indicating higher microbial activity under organic farming.

Conversion of land from conventional to organic farming found to have better soil quality in terms of higher microbial 
populations of soils which is essential for enhancing soil productivity and other functions of soil in the given ecosystem. In the present agriculture scenario, organic farming may be adopted or promoted as an alternative to the conventional farming practices for sustainable use of natural resources, particularly, with respect to the impending global food safety coupled with climate change.

\section{Acknowledgment}

The authors are thankful to CCS Haryana Agricultural University, Hisar for providing the financial assistance and other facilities to conduct this research work.

\section{References}

Amaral, H.F., J. Ozinaldo, A. Sena, K. Regina, E.F. Schwan, E.L. Balota and D.S. Andrade: Soil chemical and microbial properties in vineyards under organic and conventional management in southern Brazil. R. Bras. Ci. Solo, 35, 1517-1526 (2011).

Araujo, A.S.F.: Soil microbial activity in conventional and organic agricultural systems. Sustainability, 1, 268-276 (2009).

Bobulska, L., D. Fazekasova, L. Angelovicova and D. Kotorova: Impact of ecological and conventional farming systems on chemical and biological soil quality indices in a cold mountain climate in Slovakia. Biol. Agric. Hortic., 26, 2-17 (2015).

Bunemann, E.K., G.D. Schwenke and L.V. Zwieten: Impact of agricultural inputs on soil organisms: A review. Aust. J. Soil Res., 44, 379-406 (2006).

Carine, F., Y. Capowiez and S. Criquet: Enzyme activities in apple orchard agro-ecosystems: How are they affected by management strategy and soil properties? Soil Biol. Biochem., 41, 61-68 (2009).

Crecchioa, C., A. Gelsominob, R. Ambrosolic, J.L. Minatic and R. Ruggiero: Functional and molecular responses of soil microbial communities under differing soil management practices. Soil Biol. Biochem., 36, 1873-1883 (2004).

Dhaliwal, S.S., B. Singh, B.D. Sharma and K.L. Khera: Soil quality and yield trends of different crops in low productive submontaneous tract and highly productive area in Punjab, India. Indian J. Dryland Agric. Res. Dev., 24, 39-45 (2009).

Grayston, S., C. Campbell, R. Bardgett, J. Mawdsley, C. Clegg and K. Ritz: Assessing shifts in microbial community structure across a range of grasslands of differing management intensity using CLPP, PLFA and community DNA techniques. Appl. Soil Ecol., 25, 63-84 (2004).

Iqbal, B.A.: World food scenario: Emerging trends and issues. Afr. J. Bus. Manage., 4, 1475-1479 (2010).

Jadhav, A. B., A. D. Kadlag and V. M. Amrutsagar: Soil enzyme activities, organic carbon and microbial population as influenced by integrated nitrogen management for Banana. J. Indian Soc. Soil Sci., 64, 98-107 (2016).

Lindow, S.E., D.C. Arny and C.D. Upper: Distribution of ice nucleationactive bacteria on plants in nature. Appl. Environ. Microbiol., 36, 831-838 (1978).

Melero, S.: Chemical and biochemical properties in a silty loam soil under conventional and organic management. Soil Tillage Res., 90, 162170 (2006).

Moeskops, M.B., B. Sukristiyonubowo, D. Buchana, S. Sleutel, L. Herawaty, E. Husenb, R. Saraswati, D. Setyorini and N.S. De: Soil microbial communities and activities under intensive organic and conventional vegetable farming in West Java, Indonesia. Appl. Soil Ecol., 45, 112-120 (2010).

Pimentel, D., P. Hepperly, J. Hanson, D. Douds and R. Seidel: Environmental, Energetic and Economic comparisons of organic and conventional farming systems. Biosci., 55, 573-582 (2005).

Schjonning, P., S. Elmholt, L.J. Munkholm and K. Debosz: Soil quality aspects of humid sandy loams as influenced by organic and conventional long-term management. Agricult. Ecosys. Environ., 88, 195-214 (2002).

Sheoran, O.P., D.S. Tonk, L.S. Kaushik, R.C. Hasija and R.S. Pannu: Statistical Software Package for Agricultural Research Workers. Recent Advances in information theory, Statistics \& Computer Applications by D. S. Hooda \& R. C. Hasija Department of Mathematics Statistics, CCS HAU, Hisar. pp, 139-143 (1998).

Sudhakaran, M., D. Ramamoorthy and R.S. Kumar: Impacts of conventional, sustainable and organic farming system on soil microbial population and soil biochemical properties, Puducherry, India. Int. J. Environ. Sci., 4, 28-41 (2013).

Uddin, M.N., M.A. Siddiqy, A.M. Hossain, F. Islam, G.M.A. Halim and M.L. Bari: Impact of organic and conventional practices on, soil health and crop yield under tropical and subtropical environment of Bangladesh. Int. J. Environ. Agric. Res., 2, 89-100 (2016).

Warner, K., M. Hamza, F. Oliver-Smith, Renaud and A. Julca: Climate change, environmental degradation and migration. Nat. Hazards, 55, 689-715(2010).

Wu, T., D. Chellemi, J. Graham, K. Martin and E. Rosskop: Comparison of soil bacterial communities under diverse agricultural land management and crop production practices. Microbial. Eco., 55, 293-310(2008). 